\title{
STRATEGI PENGEMBANGAN KERIPIK JAMUR TIRAM PUTIH DI KECAMATAN RIMBO BUJANG KABUPATEN TEBO \\ (Studi Kasus Home Industry Fiisa Group)
}

\section{OTHER MUSHROOM CHIPS DEVELOPMENT STRATEGY WHITE IN RIMBO BUJANG DISTRICT TEBO DISTRICT (Fiisa Group Home Industry Case Study)}

\author{
Asminar ${ }^{1}$, Ayu Alda Vera ${ }^{2}$, dan Asnawati Is ${ }^{2}$ \\ 1, 2 Program Studi Agribisnis, Fakultas Pertanian, Universitas Muara Bungo, Jl. Pendidikan, \\ RT. 10 RW. 02 No. 10 Kelurahan Sungai Binjai. Kecamatan Bathin III. Kabupaten Bungo, \\ Jambi 37228, Indonesia \\ asminarjabir@yahoo.com, Aldaayu030@gmail.com,zahira_siregar@yahoo.co.id
}

\begin{abstract}
ABSTRAK
Jamur tiram putih merupakan salah satu jenis jamur yang banyak dikonsumsi oleh masyarakat. Penelitian ini dilaksanakan pada 10 Desember 2018 sampai 10 Januari 2019 dengan tujuan untuk mengetahui faktor internal dan eksternal dalam mengembangkan usaha keripik jamur tiram putih serta mengetahui strategi pengembangan keripik jamur tiram putih di Desa Rimbo Mulyo Kecamatan Rimbo Bujang Kabupaten Tebo.

Metode penelitian yang digunakan adalah metode survey, yaitu pada Home Industry Keripik Jamur Tiram Puth Fiisa Group di Desa Rimbo Mulyo Kecamatan Rimbo Bujang Kabupaten Tebo. Penelitian ini menggunakan Analisis SWOT.

Hasil penelitian menunjukkan bahwa Faktor internal (kekuatan dan kelemahan) yang dimiliki oleh Home Industry Keripik Jamur Tiram Putih Fiisa Group di Desa Rimbo Mulyo Kecamatan Rimbo Bujang Kabupaten Tebo adalah kekuatan berupa sumber modal sendiri, tenaga kerja sangat mudah ditemukan dan modal awal terjangkau dan kelemahannya berupa tidak adanya investasi dari pihak lain, produksi tidak menentu, dan oembukuan dilakukan setiap tahun. Sedangkan faktor eksternal adalah peluang berupa bahan baku yang tersedia, belum adanya pesaing dari produk yang sama, keiutsertaan dalam pameran dan ancamannya berupa pesaing dari produk lain, kurangnya kegiatan promosi/iklan, kurangnya mesin/alat yang digunakan, dan image jamur tiram putih yang masih asing. Strategi pengembangan pada Home Industry Keripik Jamur Tiram Putih Fiisa Group adalah Peningkatan modal dengan cara penambahan investasi atau pinjaman dari pihak lain, memperluas daerah pemasaran, pelatihan manajemen kepada pemilik usaha yang dilakukan secara berkelanjutan agar usaha berkembang, memanfaatkan modal yang ada untuk menambah produksi untuk menguasai pasar ketika belum adanya pesaing dari produk yang sama, menciptakan varian rasa baru keripik jamur tiram putih, memperluas pangsa pasar, mempertahankan kualitas produk, meningkatkan iklan/promosi, mengadakan kerjasama dengan pedagang lain dalam hingga luar wilayah, pengoptimalan penggunaan mesin/alat teknologi.
\end{abstract}

Kata Kunci : $\quad$ Analisis SWOT, Home Industry, Keripik Jamur Tiram Putih. 


\section{ABSTRACT}

White oyster mushroom is a type of mushroom that is widely consumed by the public. This research was conducted on December 10, 2018 to January 10, 2019 with the aim of knowing internal and external factors in developing white oyster mushroom chips business and knowing the development strategy of white oyster mushroom chips in Rimbo Mulyo Village, Rimbo Bujang District, Tebo Regency.

The research method used is a survey method, namely the Home Industry Fiisa Group White Oyster Mushroom Chips in Rimbo Mulyo Village, Rimbo Bujang District, Tebo Regency. This study uses a SWOT analysis.

The results showed that the internal factors (strengths and weaknesses) possessed by the Fiisa Group's White Oyster Mushroom Chips Home Industry in Rimbo Mulyo Village, Rimbo Bujang District, Tebo Regency are strengths in the form of their own source of capital, labor is very easy to find and affordable initial capital and weaknesses are there is no investment from other parties, production is uncertain, and bookkeeping is carried out annually. While external factors are opportunities in the form of available raw materials, the absence of competitors from the same product, participation in exhibitions and threats in the form of competitors from other products, lack of promotional / advertising activities, lack of machines / tools used, and the image of white oyster mushrooms that are still foreign. The development strategy for the Fiisa Group's White Oyster Mushroom Chips Home Industry is increasing capital by increasing investment or loans from other parties, expanding the marketing area, training management for business owners that are carried out in a sustainable manner so that businesses develop, utilizing existing capital to increase production to control market when there are no competitors of the same product, creating new flavors of white oyster mushroom chips, expanding market share, maintaining product quality, increasing advertising / promotion, establishing cooperation with other traders within and outside the region, optimizing the use of technology machines / too'

Keywords: SWOT analysis, Home Industry, White Oyster Mushroom Chips

\section{PENDAHULUAN}

Hortikultura merupakan salah satu subsektor pertanian yang menempati posisi penting dalam memberi kontribusi bagi perekonomian Indonesia yang mencakup atas buah-buahan, sayuran, tanaman hias, dan tanaman biofarmaka. Tanaman hortikultura mempunyai sifat yang unik yaitu mudah rusak dan pada umumnya dikonsumsi dalam keadaan segar, sehingga diperlakukan khusus dalam penanganannya (Hermayanti, 2013).

Jamur atau cendawan turut memberikan andil besar dalam memenuhi aneka ragam menu makanan khas Indonesia seperti tempe, tape, oncom, tauco, roti, minuman fermentasi serta berbagai macam makanan lainnya. Jamur merupakan salah satu jenis produk hortikultura yang dapat dikembangkan dan diarahkan untuk dapat memperbaiki keadaan gizi masyarakat. Penggunaan pestisida dalam budidaya jamur relatif sedikit. Oleh karena itu, jamur merupakan pangan yang aman untuk dikonsumsi. Selain itu dengan harga yang relatif murah, maka hampir semua kalangan mampu membelinya. Keunggulan yang spesifik dari jamur bila dibandingkan dengan tanaman lain maupun hewan adalah kemampuan dalam mengubah celulose atau lignin menjadi polisakarida dan protein yang bebas kolesterol (Pasaribu, et.al. 2002).

Jamur tiram mempunyai khasiat untuk kesehatan manusia sebagai protein nabati yang tidak mengandung kolesterol, 
sehingga dapat mencegah timbulnya penyakit darah tinggi, penyakit jantung, untuk mengurangi berat badan, obat diabetes, obat anemia dan sebagai obat anti tumor (Suriawiria, 2006). Jamur tiram memiliki kandungan nutrisi seperti protein, lemak, karbohidrat, serat, abu, kalori yang sangat bagus untuk kesehatan. Jamur yang dapat dikonsumsi (edible mushroom) dan sudah dibudidayakan di Indonesia salah satunya adalah jamur tiram putih. Jamur tiram putih (Pleurotus ostreatus) adalah jamur pangan dari kelompok Basidiomycota dan termasuk kelas Homobasidiomycetes dengan ciri-ciri umum tubuh buah berwarna putih hingga krem dan tudungnya berbentuk setengah lingkaran mirip cangkang tiram dengan bagian tengah agak cekung. Jamur tiram masih satu kerabat dengan Pleurotus eryngii dan sering dikenal dengan sebutan King Oyster Mushroom (Suriawiria, 2006).

Jamur tiram putih merupakan salah satu jenis jamur yang banyak dikonsumsi oleh masyarakat. Jamur tiram dalam bahasa latin yang disebut Pleurotus ostreatus ini merupakan jamur yang dibudidayakan pada substrat yang berbentuk serbuk kayu dan diinkubasi ke dalam kumbung. Jamur tiram sendiri memiliki beberapa keunggulan salah satunya yaitu dapat dibudidayakan dengan mudah dan juga dapat dilakukan sepanjang tahun. Pengembangan jamur tiram sendiri tidak memerlukan lahan yang luas. Masa produksi jamur tiram relatif lebih cepat sehingga periode dan waktu panen lebih singkat dapat berlanjut sepanjang tahun. Namun, jamur tiram sendiri memiliki kekurangan yaitu tidak dapat tahan lama setelah masa panen maka hari itu jamur tiram harus segera di distribusikan atau diolah (Suriawiria, 2006).

Kecamatan Rimbo Bujang sendiri terdapat banyak masyarakat yang membudidayakan jamur tiram putih, yang saat ini dijadikan bahan olahan yang dapat bertahan lama contohnya seperti menjadi olahan keripik jamur tiram putih. Keripik jamur tiram putih menjadi salah satu cara untuk meningkatkan pendapatan rumah tangga dari hasil pertanian. Produksi keripik jamur tiram putih ini masih sedikit atau tergantung pesanan sementara peminat untuk keripik jamur tiram putih ini cukup banyak, kurang luasnya pemasaran, kurang pahamnya tantang bahan baku jamur tiram itu sendiri terhadap masyarakat sehingga membuat industri ini belum berkembang. Oleh karena itu perlunya strategi pengembangan terhadap usaha ini.

Home industry Fiisa Group ini mengelola jamur tiram putih menjadi keripik jamur tiram putih yang menjadi home industry keripik jamur tiram putih satu satunya di Kecamatan Rimbo Bujang yang terdaftar berdasarkan data Dinas Perindustrian dan Perdagangan Kabupaten Tebo yang berbahan baku Pertanian. Home industry Fiisa Group menjadi satu satunya industri yang ada di Kecamatan Rimbo Bujang yaitu Keripik jamur tiram Fiisa Group yang ada di Desa Rimbo Mulyo. Tujuan dari penelitian ini adalah untuk mengidentifikasi faktor internal dan eksternal yang mempengaruhi pengembangan home industry keripik jamur tiram putih Fiisa Group dan mengetahui strategi pengembangan home industry keripik jamur tiram putih Fiisa Group Kecamatan Rimbo Bujang Kabupaten Tebo

Berdasarkan latar belakang diatas maka penulis tertarik untuk melakukan penelitian berjudul "Strategi Pengembangan Keripik Jamur Tiram Putih Di Kecamatan Rimbo Bujang Kabupaten Tebo (Studi Kasus Home industry Fiisa Group).

\section{METODOLOGI PENELITIAN}

Penelitian ini dilaksanakan di Desa Rimbo Mulyo Kecamatan Rimbo Bujang Kabupaten Tebo. Pemilihan lokasi 
dilakukan secara sengaja dengan pertimbangan daerah Desa Rimbo Mulyo Kecamatan Rimbo Bujang Kabupaten Tebo merupakan Desa yang menghasilkan Keripik jamur tiram satu-satunya di Kecamatan Rimbo Bujang (Dinas Perindustrian, Perdagangan dan Tenaga Kerja Kabupaten Tebo, 2018). Penelitian dilaksanakan dari bulan Desember 2018 sampai Januari 2019.

Data yang dikumpulkan terdiri dari data primer dan data sekunder. Data primer dikumpulkan melalui wawancara langsung dengan pengusaha yang dipandu dengan daftar pertanyaan kuesioner yang telah disiapkan, sedangkan data sekunder diperoleh dari laporan-laporan hasil penelitian, bahan bacaan serta data Dinas Perindustrian dan Perdagangan dan BPS (Badan Pusat Statistik) yang terkait dengan literature-literatur pendukung.

Metode penelitian yang digunakan dalam penelitian adalah dengan metode survei. Menurut Sugiyono (2009) metode survei digunakan untuk mendapatkan data dari tempat tertentu yang alamiah (bukan buatan) tetapi peneliti melakukan perlakuan dalam pengumpulan data, misalnya mengedarkan kuisioner, test, wawancara terstruktur dan sabagainya. Dimana dalam penelitian ini yang menjadi objek penelitian adalah industri keripik jamur tiram di Desa Rimbo Mulyo dimana Desa Rimbo Mulyo merupakan desa satusatunya yang mempunyai industri keripik jamur tiram.

Metode analisis data yang digunakan dalam penelitian ini adalah Analisis SWOT yaitu identifikasi berbagai faktor secara sistematis untuk merumuskan strategi home industry keripik jamur tiram. Análisis ini didasarkan pada logika yang dapat memaksimalkan kekuatan (Strengths) dan peluang (Opportunities), namun secara bersamaan dapat meminimalkan kelemahan (Weaknesses) dan ancaman (Threats). Perencanaan strategis home industry keripik jamur tiram (kekuatan, kelemahan, peluang dan anacaman) dalam kondisi yang ada pada saat ini. Berikut adalah langkah-langkah selanjutnya setelah diperoleh analisis mengenai kekuatan, kelemahan, peluang dan ancaman pada home industry keripik jamur tiram:

\section{Analisis Faktor Internal dan Eksternal}

Berikut ini adalah tahapan-tahapan analisis IFAS (Internal Factor Analysis Summary) dan EFAS (Eksternal Factor Analysis Summary) untuk mengidentifikasi faktor internal dan eksternal didalam perusahaan (Rangkuti, 2006) yaitu:

1. Melakukan identifikasi dan menuliskannya pada kolom 1, tentang kekuatan dan kelemahan dari perusahaan.

2. Menetapkan rating dari masingmasing faktor kekuatan dengan angka 4 (sangat penting), 3 (penting), 2 (cukup penting), 1 (tidak penting). Sedangkan kelemahan 1 (sangat penting), 2 (penting), 3 (cukup penting), 4 (tidak penting).

3. Menetapkan bobot faktor internal pada kolom 2, mulai dari 1,0 (paling penting) sampai 0,0 (tidak penting). total semua bobot harus berjumlah 1,0 .

4. Pada aspek kekuatan dan kelemahan menggunakan skala 0-1. Setiap aspek mendapatkan skor tertinggi terbanyak 0,5 . Sehingga formulasi terbaiknya adalah 0,5 di bagi angka 10. Berikut adalah formulasi perhitungan pembobotan dan rating terbaik :

a. Faktor kekuatan dan faktor peluang

Setiap rating dikalikan dengan hasil pembagian dari skor maksimum pada setiap aspek yaitu 0,5 . Berikut ini hasil perumusan bobot faktor kekuatan :

- $\quad$ Rating $1=1 \times(0,5: 10)=0,05$

- $\quad$ Rating $2=2 \times(0,5: 10)=0,10$

- $\quad$ Rating $3=3 \times(0,5: 10)=0,15$

- $\quad$ Rating $4=4 \times(0,5: 10)=0,20$ 
b. Faktor kelemahan dan ancaman Pada faktor kelemahan menggunakan rating terbalik dimana rating 4 merupakan bobot terendah. Namun pada formulasinya bobot tetap menggunakan perumusan yang sama dengan faktor kekuatan. Berikut ini perumusan bobot pada faktor kelemahan :

- $\quad$ Rating $4=1 \times(0,5: 10)=0,05$

- Rating $3=2 \times(0,5: 10)=0,10$

- Rating $2=3 \times(0,5: 10)=0,15$

- Rating $1=4 \times(0,5: 10)=0,20$

5. Mengalikan rating dengan bobot dengan peringkatnya untuk memperoleh skor terbobot yang akan ditulis pada kolom 4 .

6. Menjumlah seluruh skor terbobot sehingga memperoleh total dari skor terbobot. Total skor terbobot mempunyai interval dari angka 4,0 (baik sekali) hingga 1,0 (buruk).

Identifikasi faktor-faktor internal dan eksternal ini diperoleh dengan memanfaatkan seluruh hasil analisis. Selanjutnya informasi yang diperoleh diklasifikasikan. Pemberian bobot masingmasing skala mulai 1,0 (paling penting) sampai 0,0 (paling tidak penting), berdasarkan pengaruh tersebut. Semua bobot tersebut tidak boleh melebihi skor total 1,00. Pemberian rating untuk masingmasing faktor-faktor dengan skala mulai dari empat sampai dengan satu, berdasarkan pengaruh faktor tersebut terhadap kondisi sektor home industry keripik jamur tiram. Pemberian nilai rating untuk faktor kekuatan dan peluang yang bersifat positif semakin besar diberi rating 4. Tetapi bila kecil diberi rating 1 . Pemberian nilai rating kelemahan dan ancaman yang bersifat negatif semakin besar diberi rating 1, tetapi bila kecil diberi rating 4 .

Setelah mengumpulkan informasi yang berpengaruh terhadap kelangsungan home industry keripik jamur tiram , tahap selanjutnya adalah memanfaatkan informasi tersebut kedalam rumusan strategi. Matrik dibawah ini dapat menggambarkan secara jelas bagaimana peluang dan ancaman yang dihadapi home industry keripik jamur tiram putih sehingga dapat disesuaikan dengan kekuatan dan kelemahan yang dimiliki. Matrik ini dapat menghasilkan empat set kemungkinan alternatif strategis.

\section{Matriks IE (Internal dan Eksternal)}

Matriks Internal dan Eksternal digunakan untuk menggambarkan kondisi strategi pada suatu perusahaan. Matriks ini diperoleh dari hasil skor pada faktor internal dan eksternal. Berikut tabel matriks internal dan eksternal dapat dilihat pada Gambar

Total Faktor Strategi Internal

\begin{tabular}{ccc} 
Kuat & Rata-rata & Lemah \\
4,00 & 3,00 & 2,00 \\
\hline I & II & III
\end{tabular}

Tinggi Pertumbuhan Pertumbuhan Penciutan

\begin{tabular}{|c|c|c|c|c|}
\hline & & & & \\
\hline Total & & IV & $\mathrm{V}$ & VI \\
\hline $\begin{array}{l}\text { Faktor } \\
\text { Strategi }\end{array}$ & Menengah & Stabilitas & $\begin{array}{l}\text { Perumbuhan } \\
\text { Stabilitas }\end{array}$ & Penciutan \\
\hline Eksternal & 2.00 & VII & VIII & IX \\
\hline & & Pertumbuhan & Pertumbuhan & Likuidasi \\
\hline & 1,00 & Gambar 1. Ma & riks Internal de & n Eksterna \\
\hline
\end{tabular}


Keterangan :

I : Strategi konsentrasi melalui

integrasi vertical

II : Strategi konsentrasi melalui

integrasi horizontal

III : Strategi tumaround

IV : Strategi stabilitas

V : Strategi konsentrasi melalui horizontal atau stabilitas (tidak ada perubahan dalam pendapatan)

1. Growth strategy yang merupakan pertumbuhan perusahaan itu sendiri (sel I, II, dan V) atau upaya diversifikasi (sel VII, dan VIII)

2. Stability strategy adalah strategi yang diterapkan tanpa merubah arah strategi yang telah ditentukan.

3. Retrenchment strategy merupakan sel (III, VI, dan IX) adalah usaha untuk
VI : Strategi divestasi

VII : Strategi diversifikasi

IX : Strategi likuiditas (tidak berkembang)

Diagram tersebut dapat mengidentifikasi 9 sel strategi perusahaan, akan tetapi pada dasarnya kesembilan sel tersebut dapat dikelompokkan menjadi tiga strategi utama yang terdiri dari :

memperkecil atau mengurangi usaha yang dilakukan perusahaan.

\section{Matriks SWOT}

Matriks SWOT digunakan dalam identifikasi berbagai faktor secara sistematis untuk merumuskan strategi perusahaan. Analisis ini menggunakan logika dalam memaksimalkan pemakaian kekuatan dan peluang untuk memanipulasi kelemahan dan meminimalkan ancaman.

Tabel 1. Matrik SWOT

\begin{tabular}{|c|c|c|}
\hline EFAS & $\begin{array}{l}\text { STRENGHTS (S) } \\
\text { - Tentukan faktor- } \\
\text { faktor kekuatan } \\
\text { internal }\end{array}$ & $\begin{array}{l}\text { WEAKNESSES }(\mathrm{W}) \\
\text { - Tentukan faktor- } \\
\text { faktor kelemahan } \\
\text { internal }\end{array}$ \\
\hline \multirow{3}{*}{$\begin{array}{ll}\text { OPPORTUNITIES (O) } \\
\text { - } & \text { Menentukan } \\
& \text { faktor-faktor } \\
& \text { peluang eksternal }\end{array}$} & STRATEGI SO & STRATEGI WO \\
\hline & $\begin{array}{l}\text { Ciptakan strategi } \\
\text { yang menggunakan }\end{array}$ & $\begin{array}{l}\text { Ciptakan strategi yang } \\
\text { meminimalkan }\end{array}$ \\
\hline & $\begin{array}{l}\text { kekuatan untuk me- } \\
\text { manfaatkan peluang }\end{array}$ & $\begin{array}{l}\text { kelemahan untuk } \\
\text { memanfaatkan peluang }\end{array}$ \\
\hline \multirow[t]{4}{*}{ TREATHS (T) } & STRATEGI ST & STRATEGI WT \\
\hline & $\begin{array}{l}\text { Ciptakan strategi } \\
\text { yang menggunakan }\end{array}$ & $\begin{array}{l}\text { Ciptakan strategi yang } \\
\text { meminimalkan }\end{array}$ \\
\hline & kekuatan untuk & kelemahan dan \\
\hline & mengatasi ancaman & menghindari ancaman \\
\hline
\end{tabular}

Sumber : Freddy Rangkuti, 2009

Keterangan :

Menurut Rangkuti (2009), Apabila strategi dalam Tabel 1 dikaitkan dengan strategi bisnis, maka pilihan-pilihan strategi bisnis yang perlu dilakukan sebagai berikut :

1) Strategi SO (Strenghts-Opportunities), dalam situasi ini perusahaan perlu melakukan pengembangan bisnis yang agresif, yaitu memanfaatkan kekuatan yang substansial untuk menciptakan bisnis baru atau mengembangkan bisnis yang ada. Strategi dalam kuadran SO disebut sebagai strategi agresif.

2) Strategi ST (Strengts-Threats), dalam situasi ini perusahaan perlu melakukan diversifikasi produk atau bisnis, melalui mengembangkan produkproduk unggul. Strategi dalam kuadran ST disebut sebagai strategi diversifikasi. 
3) Srategi WO (WeaknessesOpportunities), dalam situasi ini manajemen harus melakukan analisis terhadap kelemahan sehingga mampu menghilangkan kelemahan utama itu. Strategi dalam kuadaran WO disebut sebagai strategi balik arah.

\section{HASIL DAN PEMBAHASAN}

\section{Home Industry Keripik Jamur tiram putih Fiisa Group}

Home Industry keripik jamur tiram putih yang ada di Desa Rimbo Mulyo Kecamatan Rimbo Bujang Kabupaten Tebo ini berdiri sejak tahun 2008 yaitu dengan nama usaha Home Industry Fiisa Group yang didirikan oleh Ibu Kusmartini. Adapun jenis produk yang dipasarkan oleh Home Industry Fiisa Group ini adalah jamur tiram putih segar dan berbagai olahan jamur tiram putih seperti keripik jamur tiram putih, sate jamur tiram putih, nugget jamur tiram putih dan jamur tiram putih crispy. Keripik jamur tiram putih ini adalah ide dari Ibu Kusmartini sendiri diawali dengan berwisata di daerah Malang dan melihat adanya keripik jamur tiram putih dengan prospek yang bagus sehingga tertarik untuk mencoba untuk membuka usaha keripik jamur tiram putih mengingat Ibu Kusmartini juga mempunyai pembudidayaan Jamur tiram putih itu sendiri. Awal percobaan keripik jamur tiram putih ini masih asing saat dicoba dipasarkan namun dengan berkali kali percobaan dipasaran dan mengikuti pameran maka produk ini saat ini layak dipasarkan. Lokasi usaha keripik jamur tiram putih terletak di Jl.14 Poros Unit 3 Desa Rimbo Mulyo Kecamatan Rimbo Bujang Kabupaten Tebo. Lokasi pada usaha ini sangat strategis karena berada di pinggir jalan poros Rimbo Bujang atau jalan lintas Rimbo Bujang sehingga masyarakat mudah menemukannya.

Struktur organisasi Home Indutry Keripik Jamur Tiram Putih Fiisa Group di
4) Strategi WT (Weaknesses-Threats), dalam situasi ini manajemen harus melakukan analisis terhadap kelemahan utama yang ada sekaligus menghindari ancaman. Strategi pada kuadran WT disebut sebagai strategi bertahan.

Desa Rimbo Mulyo Kecamatan Rimbo Bujang Kabupaten Tebo terdiri dari pemiik usaha yaitu Ibu Iba Kusmartini dan dua karyawan yaitu Siti dan Aan. Dilihat dari struktur organisasi yang ada dapat disimpulkan bahwa industri ini termasuk jenis Home Industry, yaitu industri rumah tangga yang menggunakan jumlah tenaga kerja 1-4 orang.

Cara pembuatan keripik jamur tiram putih milik Ibu Kusmartini di Desa Rimbo Mulyo Kecamatan Rimbo Bujang Kabupaten Tebo. Tahapan yang dilalui adalah sebagai berikut:

\section{a. Tahap Pengolahan Jamur tiram putih}

1. Memilih jamur tiram putih yang segar kemudian dibersihkan menggunakan air yang bersih

2. Jamur tiram putih yang sudah dibersihkan tadi kemudian dibagi menjadi beberapa bagian (disuir-suir) setelah itu jamur tiram putih yang sudah disuir-suir tadi dicuci kembali menggunakan air bersih lalu ditiriskan hingga kering.

\section{b. Tahap Pengolahan Keripik Jamur tiram putih}

1. Jamur tiram putih yang sudah ditiriskan tadi diadonin dengan tepung terigu yang sudah diberi air dan bumbu

2. Jamur tiram putih yang sudah diadonin tadi diayak kembali menggunakan tepung terigu kering hingga menebal

3. Jamur tiram putih yang sudah ditebali oleh tepung tadi digoreng setengan matang kemudian dimasukkan garam 
4. Jamur tiram putih yang telah diberi garam tadi digoreng kembali hingga bewarna coklat keemasan dan matang sempurna

5. Setelah matang kemudian dimasukkan ke spinner atau alat pemisah minyak sehingga kandungan minyak dalam keripik berkurang dan supaya keripik tahan lama serta tidak bau (tengik).

\section{c. Tahap Kemasan (Packing)}

Tahap yang terakhir adalah tahap kemasan (packing) yaitu keripik jamur

\section{Faktor Internal dan Eksternal Pada} Home Industry Keripik Jamur Tiram Putih Fiisa Group di Desa Rimbo Mulyo Kecamatan Rimbo Bujang Kabupaten Tebo

\section{A. Faktor Internal}

\section{- Sumber Daya Manusia (Tenaga Kerja)}

Sumber Daya Manusia (SDM) pada Home Industry Keripik Jamur Tiram Putih Fiisa Group yaitu Jumlah tenaga kerja yang ada pada Home Industry Keripik Jamur Tiram Putih Fiisa Group sebanyak 2 orang yaitu Siti dan Aan. Tingkat ketersediaan jumlah angkatan kerja yang ada di daerah Desa Rimbo Mulyo Kecamatan Rimbo Bujang Kabupaten Tebo tidaklah banyak karena masyarakat yang kurang tertarik untuk membuat keripik jamur tiram putih ini dikarenakan prosesnya yang memerlukan waktu dan ketelitian yang banyak. Oleh karena itu Ibu Kusmartini lebih mudah ini mencari sendiri tenaga kerja dari luar kota dan menawari untuk tinggal menetap di tempat tinggal yang sudah tersedia di Home Industry Fiisa Group ini. Tenaga kerja yang ada pada usaha Home Industry Keripik Jamur Tiram Putih Fiisa Group ini berasal dari masyarakat luar Kabupaten atau luar Provinsi yaitu berasal dari Kota Malang Provinsi Jawa Timur.

Pendidikan terakhir tenaga kerja yang ada pada Home Industry Keripik tiram putih tersebut dimasukkan ke dalam kemasan yaitu plastic aluminium foil dengan berat 100 gram per kemasan dan diberikan tanda merek sehingga membuat tampilan keripik lebih menarik. Harga keripik jamur tiram putih ini juga relative murah yaitu seharga Rp.10.000 per kemasan. Dengan pengolahan yang baik dan dikemas dengan baik pula keripik jamur tiram putih ini dapat bertahan selama 3 bulan tanpa bahan pengawet.

Jamur Tiram Putih Fiisa Group ini adalah Sekolah Menengah Atas (SMA). Produksi jamur tiram tidak menentu karena produksi yang tidak menentu atau sesuai pesanan. Tenaga kerja yang berada pada Home Industry Keripik Jamur Tiram Putih Fiisa Group ini tidak terikat jam kerja karena tidak setiap harinya kerja untuk membuat keripik jamur tiram putih. Untuk pelatihan keterampilan yang diberikan kepada tenaga kerja untuk meningkatkan kualitas kerja diberikan langsung oleh pemilik usaha. Pelatihan atau pembinaan yang dilakukan pemerintah sangat jarang dilakukan jika untuk pembinaan produksi keripik jamur tiram putih, tetapi pemerintah memberikan pembinaan tentang manajemen yang baik untuk para pemilik usaha.

\section{- Pemodalan}

Modal awal pada waktu mendirikan usaha Home Industry Keripik Jamur Tiram Putih Fiisa Group ini \pm Rp.1.000.000,-. Sumber modal yang diperoleh yaitu sumber modal sendiri. Tidak ada bantuan modal dari pemerintah untuk usaha ini. Usaha Home Industry Keripik Jamur Tiram Putih Fiisa Group ini tidak ada investasi dari pihak manapun. Biaya yang dikeluarkan untuk membayar karyawan perbulan lebih dari Rp.700.000,yaitu bisa sampai Rp.1.000.000,dikarenakan tergantung seberapa banyak produksi yang dihasilkan dan ketika tidak 
memproduksi keripik, maka karyawan bekerja pada pembudidayaan jamur tiram putih milik Ibu Kusmartini sendiri.

Biaya yang dikeluarkan untuk pembelian bahan baku per bulannya sebanyak Rp. 1.000.000,- setiap bulannya dan biaya yang dikeluarkan untuk biaya operasional adalah sebanyak Rp. 150.000,- Rp.200.000,- setiap bulannya. Sistem administrasi keuangan pada usaha Home Industry Keripik Jamur Tiram Putih Fiisa Group ini adalah memisahkan semua uang milik pribadi dengan uang usaha.Pembukuan keuangan menyangkut modal, biaya produksi dan penjualan dilakukan setiap tahunnya. Perputaran modal pada usaha ini kurang lancar dikarenakan produksi yang tidak menentu setiap bulannya.

\section{B. Faktor Eksternal \\ - Pemasaran}

Bahan baku yaitu Jamur Tiram Putih ini sangat mudah didapatkan dikarenakan Ibu Kusmartini ini memiliki sendiri pembudidayaan Jamur Tiram Putih. Kualitas produk keripik jamur tiram putih sangat baik. Harga keripik jamur tiram putih terjangkau. Pemasaran produk keripik jamur tiram putih ini yaitu lokal (sekitar Rimbo Bujang), luar kabupaten hingga luar provinsi. Pendapatan perbulan dari usaha Home Industry Keripik Jamur Tiram Putih Fiisa Group adalah \pm dari Rp.5.000.000,-.

Kegiatan Promosi/iklan kurang banyak dilakukan. Upaya yang dilakukan untuk menarik pembeli yaitu dengan cara mengikuti pameran dengan mengikuti acara pameran tersebut sangat berpengaruh dalam meningkatkan penjualan. Kendala yang sangat berarti dalam pemasaran produk keripik jamur tiram putih ini adalah image bahan baku (jamur tiram putih) yang masih asing di masyarakat karena menilai semua jamur beracun. tingkat persaingan dalam industri lain yang sejenis sangat banyak. Sedangkan tingkat persaingan dalam usaha Home Industry Keripik Jamur Tiram Putih Fiisa Group ini tidak ada karena usaha ini adalah usaha olahan Jamur Tiram Putih satu-satunya di Kecamatan Rimbo Bujang.

\section{- Teknologi}

Alat atau mesin yang digunakan dalam proses produksi pada usaha Home Industry Keripik Jamur Tiram Putih Fiisa Group adalah mesin atau alat tepat guna yaitu spinner. Spinner adalah alat pemisah minyak dari keripik agar kandungan minyak atau kadar minyak rendah dan membuat keripik mempunyai daya tahan selama 3 bulan. Jumlah mesin atau alat yang digunakan dalam prose usaha Home Industry Keripik Jamur Tiram Putih Fiisa Group ini adalah sebanyak 1 unit yaitu spinner. Kualitas alat atau mesin yang digunakan sangat baik. Teknisi alat atau mesin yang digunakan dalam proses produksi ini kurang tersedia. Selanjutnya kemasan yang digunakan untuk hasil produksi ini adalah plastik aluminium foil. Kualitas kemasan yang digunakan sangat baik. Penggunaan merek pada kemasan yang digunakan jelas. Lama waktu yang dibutuhkan dari proses awal sampai produk siap jual adalah 8 jam dalam sehari. Letak lokasi pada usaha Home Industry Keripik Jamur Tiram Putih Fiisa Group ini strategis karena berada di pinggir jalan utama Rimbo Bujang atau jalan poros Rimbo Bujang. Mobilitas pada usaha Home Industry Keripik Jamur Tiram Putih Fiisa Group kurang lancar karena produksi yag tidak menentu.

\section{Analisis Faktor Internal dan Eksternal Home Industry Keripik Jamur tiram putih Fiisa Group di Desa Rimbo Mulyo Kecamatan Rimbo Bujang Kabupaten Tebo. a) Analisis Faktor Internal}

Faktor internal terdiri dari kekuatan dan kelemahan yang ada pada usaha Home Industry Keripik Jamur tiram putih di Desa Rimbo Mulyo Kecamatan Rimbo Bujang 
Kabupaten Tebo. Faktor kekuatan dan kelemahan didapat dari kuesioner yang dilakukan secara wawancara langsung kepada pemilik usaha keripik jamur tiram putih, kemudian rating dan bobot diperoleh dari kuesioner tersebut. Menurut Rangkuti (2006), pemberian bobot pada analisis faktor internal dan eksternal tidak boleh melebihi 1,00. Hal ini dapat dilihat pada Tabel 2, yang menunjukkan bahwa kekuatan yang dimiliki oleh usaha keripik jamur tiram putih Fiisa Group di Desa Rimbo Mulyo Kecamatan Rimbo Bujang Kabupaten Tebo ini adalah sumber modal yang merupakan modal Ibu Kusmartini itu sendiri dengan skor 0,80 dan tenaga kerja sangat mudah ditemukan dengan skor 0,80 selanjutnya yaitu modal awal terjangkau dengan skor 0,05 dengan begitu dapat mempermudah dalam pengembangan usaha keripik jamur tiram putih ini.

Tabel 2. Faktor-faktor Strategi Internal

\begin{tabular}{|c|c|c|c|}
\hline Faktor-faktor Internal & Bobot & Rating & Bobot X Rating \\
\hline \multicolumn{4}{|l|}{ Kekuatan } \\
\hline 1. Sumber modal sendiri & 0,20 & 4 & 0,80 \\
\hline $\begin{array}{l}\text { 2. Tenaga Kerja sangat mudah } \\
\text { ditemukan }\end{array}$ & 0,20 & 4 & 0,80 \\
\hline 3. Modal awal terjangkau & 0.05 & 1 & 0,05 \\
\hline \multicolumn{4}{|l|}{ Kelemahan } \\
\hline $\begin{array}{l}\text { 1. Tidak adanya investasi dari pihak } \\
\text { lain }\end{array}$ & 0,20 & 1 & 0,20 \\
\hline 2. Produksi tidak menentu & 0,20 & 1 & 0,20 \\
\hline \multirow[t]{2}{*}{ 3. Pembukuan dilakukan setiap tahun } & 0,15 & 2 & 0,30 \\
\hline & $\mathbf{1 , 0 0}$ & & 2,35 \\
\hline
\end{tabular}

Sumber : Analisis Data Primer (2019)

Home industry keripik jamur tiram putih Fiisa Group di Desa Rimbo Mulyo Kecamatan Rimbo Bujang Kabupaten Tebo ini juga memiliki kelemahan yaitu tidak adanya investasi dari pihak lain dengan skor 0,20 dan produksi tidak menentu atau tergantung pesanan dengan skor 0,20 yang berakibat usaha ini belum berjalan dengan baik selanjutnya yaitu pembukuan dilakukan setiap tahun dengan skor 0,15 . Penggabungan faktor kekuatan dan kelemahan memperoleh total skor 2,35 .

\section{b) Analisis Faktor Eksternal}

Faktor eksternal terdiri dari peluang dan ancaman yang ada pada usaha Home Industry Keripik Jamur tiram putih di Desa Rimbo Mulyo Kecamatan Rimbo Bujang Kabupaten Tebo. Faktor peluang dan ancaman didapat dari kuesioner yang dilakukan secara wawancara langsung kepada pemilik usaha keripik jamur tiram putih, kemudian rating dan bobot diperoleh dari kuesioner tersebut, hal ini dapat dilihat pada Tabel 3. 
Jurnal Agri Sains Vol. 4 No. 2, Desember (2020)

Tabel 3. Faktor-faktor Strategi Eksternal

\begin{tabular}{lccc}
\hline \multicolumn{1}{c}{ Faktor-faktor Eksternal } & Bobot & Rating & $\begin{array}{c}\text { Bobot X } \\
\text { Rating }\end{array}$ \\
\hline $\begin{array}{l}\text { Peluang } \\
\text { 1. Bahan baku yang tersedia }\end{array}$ & 0,20 & 4 & 0,80 \\
2. Belum adanya pesaing dari & 0,05 & 1 & 0,05 \\
$\begin{array}{l}\text { produk yang sama } \\
\text { 3. Keikutsertaan dalam pameran }\end{array}$ & 0.20 & 4 & 0,80 \\
$\begin{array}{l}\text { Ancaman } \\
\text { 1. Pesaing dari produk lain }\end{array}$ & & & \\
2. Kurangnya \\
$\begin{array}{l}\text { promosi/iklan kegiatan } \\
\text { 3. Kurangnya mesin/alat yang }\end{array}$ & 0,05 & 4 & 0,20 \\
$\quad \begin{array}{l}\text { digunakan } \\
\text { 4mage jamur tiram putih yang }\end{array}$ & 0,20 & 1 & 0,30 \\
$\quad$\begin{tabular}{l} 
masih asing di masyarakat \\
\hline
\end{tabular} & 0,15 & 2 & 0,30 \\
\hline
\end{tabular}

Sumber : Analisis Data Primer (2019)

Tabel 3 menunjukkan bahwa peluang yang dimiliki oleh usaha keripik jamur tiram putih Fiisa Group di Desa Rimbo Mulyo Kecamatan Rimbo Bujang Kabupaten Tebo adalah bahan baku yang tersedia memiliki skor 0,80 dikarenakan bahan baku yaitu jamur tiram putih ini sangat tersedia karena selain keripik jamur tiram putih tiram ini ibu Kusmartini juga memiliki pembudidayaan jamur tiram putih tiram sendiri sehingga memudahkan untuk persediaan bahan baku untuk pembuatan keripik jamur tiram putih. Kemudian belum adanya pesaing dalam usaha keripik jamur tiram putih ini memiliki skor 0,05 selanjutnya keiukutsertaan dalam pameran memiliki skor 0,80 .

Home industry keripik jamur tiram putih Fiisa Group di Desa Rimbo Mulyo Kecamatan Rimbo Bujang Kabupaten Tebo ini juga terdapat berbagai ancaman yaitu pesaing dari industri lain yang sejenis seperti industri olahan keripik lainnya yang menjadi ancaman bagi usaha ini memiliki skor 0,20 kemudian

kurangnya kegiatan promosi/iklan yang menyebabkan masyarakat kurang mengetahui tentang produk ini memiliki skor 0,30 . Kurangnya mesin/alat yang digunakan memiliki skor 0,20 selanjutnya yang terakhir adalah image jamur tiram putih yang masih asing di masyarakat memiliki skor 0,30 dikarenakan masyarakat beranggapan bahwa semua jenis jamur beracun. Penggabungan antara faktor peluang dan ancaman yang ada pada usaha keripik jamur tiram putih tiram ini memiliki skor 2,65.

a. Matriks IE (Internal dan Eksternal)

Dari total skor yang diperoleh, yaitu faktor strategis internal 2,35, sedangkan total skor yang diperoleh dari analisis faktor eksternal adalah sebesar 2,65. Dengan demikian posisi usaha Home Industry Keripik Jamur Tiram Putih Fiisa Group dapat dilihat pada gambar 2. 


\section{Gambar 2. Matriks Internal dan Eksternal Home Industry Keripik Jamur Tiram Putih} Fiisa Group

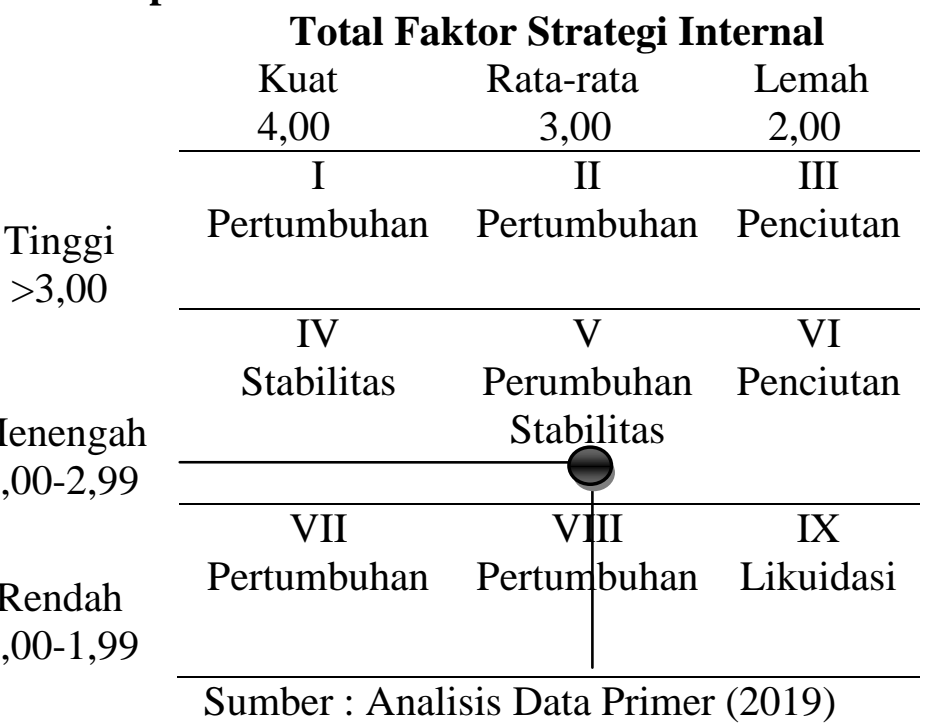

Gambar 2 menunjukkan skor yang diperoleh dari faktor strategis internal 2,35 dan faktor strategis eksternal 2,65 menunjukkan titik koordinat terletak pada daerah pertumbuhan V. Sehingga strategi yang tepat untuk digunakan dalam pengembangan Home Industry Keripik Jamur Tiram Puth Fris Group di Desa Rimbo Mulyo Kecamatan Rimbo Bujang Kabupaten Tebo adalah strategi pertahankan dan pelihara. Strategi yang digunakan adalah strategi konsentrasi melalui horizontal atau stabilitas seperti mempertahankan kualitas produk, memperluas pangsa pasar sehingga produk lebih terkenal, peningkatan teknologi tepat guna dan pengembangan kerja sama antar industry dapat dilakukan pada usaha Home Industry Keripik Jamur Tiram Putih Fiisa Group di Desa Rimbo Mulyo Kecamatan Rimbo Bujang Kabupaten Tebo. c) Matriks SWOT Strategi Pengembangan Home Industry Keripik Jamur tiram putih Fiisa Group di Desa Rimbo Mulyo Kecamatan Rimbo Bujang Kabupaten Tebo.

Matriks SWOT digunakan untuk menyusun strategi perusahaan matriks ini dapat menggambarkan secara jelas bagaimana peluang dan acaman eksternal yang dihadapi perusahaan dapat disesuaikan dengan kekuatan dan kelemahan yang dimilikinya.

Matrik SWOT digunakan dalam identifikasi berbagai faktor secara sistematis untuk merumuskan strategi perusahaan. Analisis ini menggunakan logika dalam memaksimalkan pemakaian kekuatan dan peluang untuk memanipulasi kelemahan dan meminimalkan ancaman. Matriks SWOT Strategi Pengembangan Home Industry Keripik Jamur tiram putih Fiisa Group di Desa Rimbo Mulyo Kecamatan Rimbo Bujang Kabupaten Tebo dapat dilihat pada tabel 3 yang menunjukkan bahwa hasil dari identifikasi faktor internal berupa kekuatan dan kelemahan dan faktor eksternal berupa peluang dan ancaman dalam 
mengembangkan usaha Home Industry Keripik Jamur tiram putih Fiisa Group di Desa Rimbo Mulyo Kecamatan Rimbo Bujang Kabupaten Tebo antara lain didapatkan strategi sebagai berikut:

1. Strategi S-O (Strenght-Opportunity) Strategi S-O (Strenght-

Opportunities) atau kekuatan-peluang adalah strategi yang digunakan untuk memaksimalkan kekuatan dan memanfaatkan peluang yang ada, yaitu:
a. Peningkatan modal dengan cara penambahan investasi atau pinjaman dari pihak lain (SO-1)
b. Memperluas daerah pemasaran. 
Tabel 3. Matriks SWOT Strategi Pengembangan Home Industry Keripik Jamur tiram putih Fiisa Group di Desa Rimbo Mulyo Kecamatan Rimbo Bujang Kabupaten Tebo

\begin{tabular}{|c|c|c|}
\hline EFAS & $\begin{array}{l}\quad \text { STRENGHT (S) } \\
\text { 1. Sumber modal sendiri } \\
\text { 2. Tenaga Kerja sangat } \\
\text { mudah ditemukan } \\
\text { 3. Modal awal terjangkau }\end{array}$ & \begin{tabular}{ll}
\multicolumn{1}{c}{ WEAKNESS $(\mathbf{W})$} \\
1. Kurang lancarnya perputaran \\
modal \\
2. Produksi tidak menentu \\
3. Pembukuan dilakukan setiap \\
tahun
\end{tabular} \\
\hline $\begin{array}{l}\text { OPPORTUNITY }(\mathbf{O}) \\
\text { 1. Bahan baku yang } \\
\text { tersedia } \\
\text { 2. Belum adanya } \\
\text { pesaing dari } \\
\text { produk yang sama } \\
\text { 3. Keikutsertaan } \\
\text { dalam pameran }\end{array}$ & 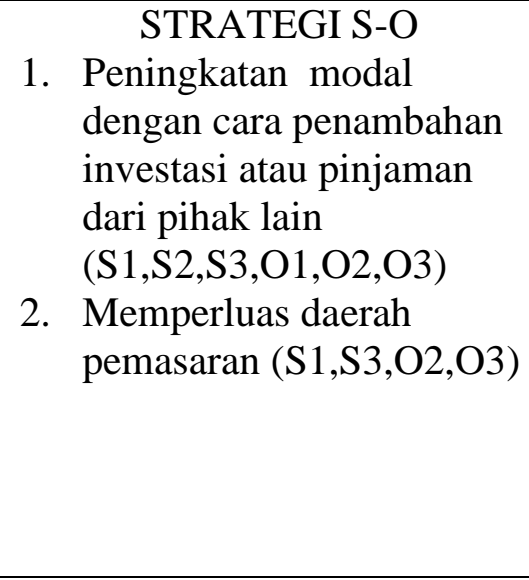 & \begin{tabular}{l}
\multicolumn{1}{c}{ STRATEGI W-O } \\
1. Pelatihan manajemen kepada \\
pemilik usaha yang dilakukan \\
secara berkelanjutan agar usaha \\
berkembang \\
(W1,W2,W3,O1,O2,O3) \\
2. Memanfaatkan modal yang ada \\
untuk menambah produksi untuk \\
menguasai pasar ketika belum \\
adanya pesaing dari industri \\
keripik jamur tiram putih yang \\
lainnya (W1,W1,W3,O1,O2)
\end{tabular} \\
\hline $\begin{array}{ll}\text { TREATH (T) } \\
\text { 1. Pesaing dari produk } \\
\text { lain yang sejenis } \\
\text { 2. Kurangnya } \\
\text { kegiatan } \\
\text { promosi/iklan } \\
\text { 3. Kurangnya } \\
\text { mesin/alat yang } \\
\text { digunakan } \\
\text { 4. Image jamur tiram } \\
\text { putih yang masih } \\
\text { asing di masyarakat }\end{array}$ & $\begin{array}{l}\text { STRATEGI S-T } \\
\text { 1. } \begin{array}{l}\text { Menciptakan varian rasa } \\
\text { baru keripik jamur tiram } \\
\text { putih }(\mathrm{S} 1, \mathrm{~T} 1, \mathrm{~T} 2, \mathrm{~T} 4)\end{array} \\
\text { 2. } \\
\text { Memperluas pangsa pasar } \\
\text { seperti pasar modern } \\
\text { (S1,S2,T1,T2,T3,T4) } \\
\text { 3. Mempertahankan kualitas } \\
\text { produk agar tetap mampu } \\
\text { bersaing dengan produk } \\
\text { lain }(\mathrm{S} 1, \mathrm{~T} 1, \mathrm{~T} 4)\end{array}$ & 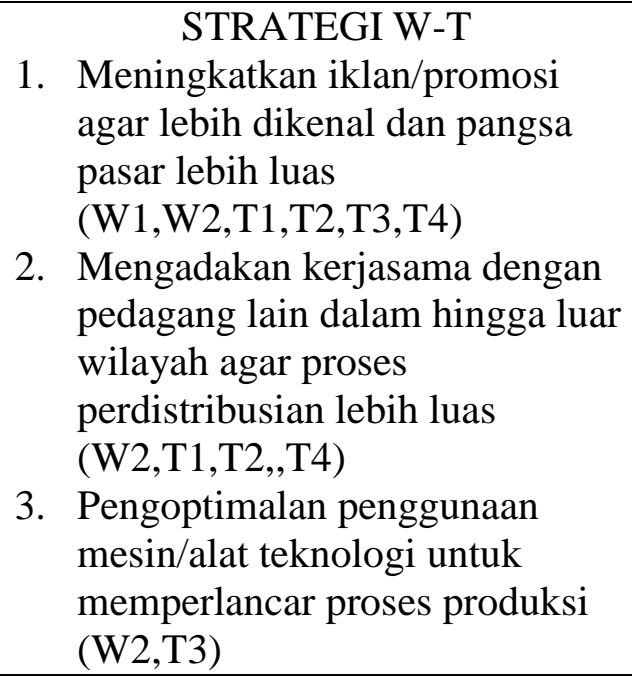 \\
\hline
\end{tabular}

Sumber : Analisis Data Primer (2019) 


\section{Strategi W-O (Weakness-Opportunity)

$$
\text { Strategi W-O (Weakness- }
$$

Opportunities) atau kelemahan-peluang adalah strategi yang digunakan untuk meminimalkan kelemahan dan memanfaatkan peluang yang ada, yaitu:

a. Pelatihan manajemen kepada pemilik usaha yang dilakukan secara berkelanjutan agar usaha berkembang (WO-1)

b. Memanfaatkan modal yang ada untuk menambah produksi untuk menguasai pasar ketika belum adanya pesaing dari industri keripik jamur tiram putih yang lainnya (WO-2).

\section{Strategi S-T (Strenght-Treaths)}

Strategi S-T (Strenght-Treaths)

atau strategi kekuatan-ancaman adalah strategi yang digunakan untuk memaksimalkan kekuatan dan mengatasi ancaman. Alternatif strategi yang

dilakukan adalah sebagai berikut:
a. Menciptakan varian rasa baru keipik jamur tiram putih (ST-1)
b. Memperluas pangsa pasar seperti pasar modern (ST-2)
c. Mempertahankan kualitas produk agar tetap mampu bersaing dengan produk lain (ST-3)

4. Strategi W-T (Weakness-Treaths)

Strategi W-T (Weakness-Treaths) atau kelemahan-ancaman merupakan strategi yang digunakan untuk meminimalkan kelemahan dan mengatasi ancaman. Alternatif strategi yang digunakan adalah sebagai berikut:

a. Meningkatkan iklan/promosi agar lebih dikenal dan meluaskan pangsa pasar (WT-1)

b. Mengadakan kerjaama dengan pedagang lain baik di dalam maupun di luar wilayah agar proses perdistribusian lebih luas (WT-2)

c. Pengoptimalan penggunaan mesin/alat teknologi untuk memperlancar proses produksi (WT-3).

\section{KESIMPULAN DAN SARAN}

1. Kesimpulan

1. Faktor internal dan eksternal

a) Faktor Internal (kekuatan dan kelemahan)

Home Industry Keripik Jamur tiram putih Fiisa Group di Desa Rimbo Mulyo Kecamatan Rimbo Bujang Kabupaten Tebo memiliki faktor internal berupa kekuatan dan kelemahan sebagai berikut :

- Kekuatan : Sumber modal sendiri, Tenaga kerja sangat mudah ditemukan, Modal awal terjangkau,

- Kelemahan : Kurang lancarnya perputaran modal, Produksi tidak menentu dan Pembukuan dilakukan setiap tahun.

b) Faktor eksternal (peluang dan ancaman)

Home Industry Keripik Jamur tiram putih Fiisa Group di Desa Rimbo Mulyo Kecamatan Rimbo Bujang Kabupaten Tebo juga memiliki faktor eksternal berupa peluang dan ancaman sebagai berikut :

- Peluang : Bahan baku yang tersedia, Belum adanya pesaing dari produk yang sama, dan Keiutsertaan dalam pameran

- Ancaman : Pesaing dari produk lain yang sejenis, Kurangnya kegiatan promosi/iklan, Kurangnya mesin/alat yang digunakan, dan Image jamur tiram putih yang masih asing.

2. Strategi pengembangan yang tepat digunakan untuk Home Industry Keripik Jamur tiram putih Fiisa Group di Desa Rimbo Mulyo Kecamatan Rimbo Bujang Kabupaten Tebo adalah sebagai berikut :

a. Peningkatan modal dengan cara penambahan investasi atau pinjaman dari pihak lain 
b. Memperluas daerah pemasaran

c. Pelatihan manajemen kepada pemilik usaha yang dilakukan secara berkelanjutan agar usaha berkembang

d. Memanfaatkan modal yang ada untuk menambah produksi untuk menguasai pasar ketika belum adanya pesaing dari industri keripik jamur tiram putih yang lainnya.

e. Menciptakan varian rasa baru keripik jamur tiram putih

f. Mempeluas pangsa pasar seperti pasar modern

g. Mempertahankan kualitas produk agar tetap mampu bersaing dengan produk lain

h. Meningkatkan iklan/promosi agar lebih dikenal dan pangsa pasar luas

i. Mengadakan kerjasama dengan pedagang lain di dalam hingga luar wilayah agar proses perdistribusian lebih luas.

j. Pengoptimalan penggunaan mesin/alat teknologi untuk memperlancar proses produksi

\section{DAFTAR PUSTAKA}

Dinas Perindustrian, Perdagangan dan Tenaga Kerja Kabupaten Tebo. 2018. Jumlah Industri di Kabupaten Tebo.

Hermayanti O. 2013. Strategi pengembangan usaha tani jamur tiram putih (Pleurotus ostreatus) di dataran rendah [skripsi]. Bogor (ID): Institut Pertanian Bogor

Pasaribu, T., Permana, D.R, Alda, E. R. 2002. Aneka Jamur Unggulan yang Menembus Pasar. PT. Grasindo; Jakarta.

Rangkuti, F. 2005. Analisis SWOT : Teknik Membedah Kasus Bisnis. PT Gramedia; Jakarta.

Rangkuti, F. 2006. Analisis SWOT Membedah Teknik Kasus Bisnis. PT.

\section{Saran}

1. Home Industry Keripik Jamur tiram putih Fiisa Group di Desa Rimbo Mulyo Kecamatan Rimbo Bujang Kabupaten Tebo bisa memanfaatkan media online seperti facebook, twitter dan instagram sebagai sarana pemasaran keripik jamur tiram putih untuk meningkatkan penjualan.

2. Home Industry Keripik Jamur tiram putih Fiisa Group di Desa Rimbo Mulyo Kecamatan Rimbo Bujang Kabupaten Tebo lebih meningkatkan kegiatan promosi produk agar industry keripik dikenal masyarakat secara umum dan menjangkau pasar yang lebih luas sehingga dapat bersaing dengan industry sejenis dari daerah lain. Mempertahankan ciri khas cita rasa produk dan meningkatkan kualitas produk salah satunya dengan cara menciptakan inovasi dalam pengemasan produk, penambahan jenis produk agar memiliki daya tarik yang tinggi agar tetap mampu bersaing dengan produk lain.

Gramedia Pustaka Umum. Bernard. Scott A; Jakarta.

Rangkuti, F. 2009. Analisis SWOT Teknik Membedah Kasus Bisnis, cetakan 16.

PT. Gramedia Pustaka Utama; Jakarta.

Suriawiria, U. 1986. Pengantar Untuk Mengenal dan Menanam Jamur. Penerbit Angkasa, Bandung.

Suriawiria, U. 2006. Budidaya Jamur Tiram. Penerbit Kanisius; Yogyakarta. 